\title{
Research on the Application of Network Education Learning in Colleges and Universities in the Information Age
}

\author{
Jian Zhang ${ }^{1, *}$ and Jing Wang ${ }^{2}$
}

\author{
${ }^{1}$ School of Management, Tianjin University of Traditional Chinese Medicine, Tianjin, China \\ ${ }^{2}$ Graduate School, Tianjin University of Traditional Chinese Medicine, Tianjin, China \\ *Corresponding author. Email: zjian619@126.com
}

\begin{abstract}
The coming of the Internet era makes more and more universities begin to use network teaching, which has promoted the development of the cause of China's education to a certain extent. The purpose of this paper is to investigate whether network teaching in colleges and universities can meet the daily learning needs of students. In this paper, the author shall obtain data through questionnaire design and use EXCEL 2010 to extract data, and analyze the data with the SPSS 21.0 software. The results show that there are three factors for students to consider whether online teaching can meet their learning needs, namely the national policy, environmental factors, and personal ability. The innovation of this paper lies in the in-depth study of whether college online teaching can meet the daily learning needs of students through online and offline questionnaire surveys.
\end{abstract}

Keywords: information age, colleges, network, teaching

\section{INTRODUCTION}

\subsection{Background}

Most foreign scholars hold a more supportive attitude towards online teaching, they think that the online teaching system is better than the offline traditional teaching mode, and the development of online teaching system in foreign countries is relatively mature, especially in the United States, they have more than 20 years of online teaching history. Some domestic scholars think that network teaching can promote the development of education in our country, in addition, it realizes the sharing of learning resources among colleges and universities, while some other scholars also think that network teaching also has drawbacks, such as "teaching by words and deeds". Through network teaching teachers can only do words teaching, failing to achieve practical teaching. There is no clear answer on whether network teaching can actively promote the development of students' learning. Because of domestic scholars only study the advantages and disadvantages of network teaching at the theoretical level, and they fail to investigate whether the network teaching can meet the needs of students' daily life learning, there is certain value on the investigation in this paper.

\subsection{What does this Article add?}

Based on the previous researches by domestic and foreign scholars, this paper researches whether network teaching can satisfy students' daily study and life by reading literature, questionnaires, and data analysis. This paper starts from the perspective of students' online learning effects, and research this issue.

\section{LITERATURE REVIEW}

This paper mainly investigates whether the application of network teaching in colleges and universities can meet the daily learning needs of students.

1) William B. Root et al. (2020)[1] believed that online education shall provide individualization, programming, and the practicability and simplicity of self-paced instructions, which are essential in the information age. This kind of programmed network teaching leads the way of the development of teaching science.

2) Xiang, L et al. (2017)[2] thought that in the view of the interactivity, openness, intelligence and adaptability of online education, which can stimulate students' learning initiative and realize real-time interaction and cooperation between teachers and students.

3) Al-Neklawy et al. (2017)[3] believed that although traditional teaching and lectures were considered to be effective in providing information and explanations, they usually cannot provide enough time for deep learning 
activities, while online education management can promote teachers to manage educational courses for students.

4) T Smith et al. (2019)[4] collected students' views on online courses and learning experience, obtaining the conclusion that this kind of online education can promote the development of teachers to some extent, in addition, the way of network teaching can broaden the horizons of students and teachers.

5) Liu, Sannyuya et al. (2020)[5] believed that online learning and teaching had become the main form of education during the global epidemic, which can provide everyone with equal educational opportunities. This online learning system is becoming more and more important for the sustainability of education. The time students spent on the online learning system can affect the sustainability and fairness and persistence of education.

6) At present, China has promulgated relevant policies to promote the development of network education. We will implement the Education Informatization 2.0 action plan, which shall scientifically advance the building of an education network, and improve the national digital education resources public service system.

Wu Jinna et al. (2015)[6] believed that in the current era of diversified communication, we should change the traditional teaching mode by taking the applied online technology education as the main part and focusing on the application as the basis to update the current teaching concepts.

Yu Leixin et al. (2020)[7] thought that the content of online education was extremely abundant, and the enrichment of teaching resources in universities made the online materials available for class diversified, which can not only broaden traditional teaching content field, but also improve the teaching quality of management.

Pei Jinhong et al. (2020)[8] believed that based on the "completely online" teaching model during the epidemic period, completely cut off the face-to-face communication among teachers and students and among students and students. Actually, although it brought some difficulties in teaching, at the same time, it can also stimulate students' learning self-consciousness and enhance their selfdiscipline ability because of the loss of reliance on classroom teaching.

Lu Zhaoyang et al. (2020)[9] thought that network education in universities was becoming more and more mature with the development of the current information age in China. The current online teaching is developing from the simple traditional online teaching mode to the compound teaching mode. In fact, this teaching mode can better meet the needs of modern teaching in our country. Qian Xinxin (2020)[10] believed that the online teaching model is not only flexible and changeable, being not limited to the location, but also has a high utilization rate of teaching resources. However, compared with offline traditional teaching, offline teaching has a better discipline.

\section{METHOD}

This paper investigated whether online teaching can meet the learning needs of students. By designing a questionnaire, which it includes the questions such as the gender, grade, contract degree of network teaching, online learning effects, whether online teaching can meet learning needs, and which teaching mode is more inclined. In addition, SPSS 21.0 data analysis software was used to conduct frequency analysis and chi-square test of the above survey content. Among them, $\mathrm{P}<0.05$ is considered to be statistically significant. Based on the above analysis, it concludes that the influencing factors about the students consider whether the network teaching can meet the learning needs.

\section{RESULT AND ANALYSIS}

\subsection{Data Sources and Results}

A total of 352 questionnaires were issued in the survey, among which 317 valid questionnaires were returned. The effective recovery rate of the questionnaire was $90.1 \%$, of which 146 were males, accounting for $46.1 \%$, and 171 were females, accounting for $53.9 \%$. In general, there are few differences in the ratio of men to women. In this survey, the proportion of people with a college degree and above accounted for $60.88 \%$, the highest proportion, the primary school degrees were followed by, accounting for $20.19 \%$, the third one was the junior high school degrees, accounting for $10.73 \%$, and finally, it was the high school degrees, accounting for $8.2 \%$. 
Table 1 Basic Information

\begin{tabular}{|c|c|}
\hline Data Sources & Total-n(\%) \\
\hline Sex-\% & $171(53.9)$ \\
\hline Female & $146(46.1)$ \\
\hline Male & $64(20.2)$ \\
\hline Grade-\% & $34(10.7)$ \\
\hline Primary school & $26(8.2)$ \\
\hline Junior school & $193(60.9)$ \\
\hline High school & \\
\hline University & $66(20.8)$ \\
\hline Internet Exposure-(\%) & $151(47.6)$ \\
\hline Always & $100(31.5)$ \\
\hline Often & $198(62.5)$ \\
\hline Sometimes & $119(37.5)$ \\
\hline Meet Demand-(\%) & \\
\hline Yes & 1901 \\
\hline No & \\
\hline
\end{tabular}

progress has a certain impact on the learning effect of online teaching. The results show that: in the process of

\subsection{Result Analysis}

The two principles of whether it can keep up with the progress of the online classroom and the learning effect of online teaching. The chi-square value is 39.720 , the progress significance is 0.000 , and $\mathrm{P}<0.05$, which shows that whether students can keep up with the classroom online teaching, students who can usually keep up with the progress of online classroom have better learning effects, while students who can only follow the class progress occasionally have slightly worse learning effects.

Table 2 Cross-linked Table Analysis

\begin{tabular}{|c|c|c|c|c|}
\hline \multicolumn{2}{|c|}{} & \multicolumn{3}{c|}{ Class progress } \\
\cline { 2 - 4 } \multicolumn{2}{|c|}{ Learning effect } & Always & Often & Sometimes \\
\cline { 2 - 4 } & Super & 21 & 22 & 16 \\
\cline { 2 - 4 } & Good & 14 & 73 & 10 \\
\hline Total & 14 & 98 & 79 \\
\hline Pearson Chi-Square & 49 & 193 & $39.720^{\mathrm{a}}$ \\
\hline \multicolumn{2}{|c|}{0.000} \\
\hline
\end{tabular}

In this questionnaire survey, 119 people hold the opinion that online teaching cannot satisfy their daily learning needs. The reasons include: $88.24 \%$ think that students' self-discipline ability is relatively poor, $78.51 \%$ think that teacher management is difficult, $76.47 \%$ think that teacherstudent interaction is poor, $73.11 \%$ think that long-term online teaching will cause myopia, and $66.39 \%$ think that there is little communication among students, and $26.05 \%$ think that the technical equipment is insufficient. From the above data, we can see that the poor self-discipline ability of students is an important factor for the reason that network teaching cannot satisfy students' needs.

Table 3 Frequency Analysis

\begin{tabular}{|c|c|c|c|}
\hline \multicolumn{4}{|c|}{ The reasons why network teaching cannot meet the needs of the daily life of students } \\
\hline \multirow{4}{*}{ Valid } & Factor & Frequency & Percent \\
\cline { 2 - 4 } & Poor self-discipline of students & 105 & $88.24 \%$ \\
\cline { 2 - 4 } & Difficult management of teacher & 93 & $78.51 \%$ \\
\cline { 2 - 4 } & Poor teacher-student interaction & 91 & $76.47 \%$ \\
\cline { 2 - 4 } & Online teaching is prone to myopia & 87 & $66.11 \%$ \\
\cline { 2 - 4 } & Little communication among students & 79 & $26.05 \%$ \\
\cline { 2 - 4 } & Lack of technical equipment & 31 & \\
\hline
\end{tabular}

In this questionnaire survey, 198 people believe that learning through online teaching platforms (Ding Talk,
WeChat, Rain Classroom, Learning, Tencent Conference) can meet their daily learning and living demands 
Table 4 Chi-square Test Analysis

\begin{tabular}{|c|c|c|c|}
\hline \multicolumn{4}{|c|}{ Chi-Square test of network teac } \\
\hline \multicolumn{2}{|c|}{ Factors } & $\begin{array}{c}\text { Sample } \\
N\end{array}$ & \begin{tabular}{l|l}
$\boldsymbol{Y}$ \\
\end{tabular} \\
\hline \multirow{2}{*}{\multicolumn{2}{|c|}{ Resource Sharing }} & $\begin{array}{c}\text { Observed } \\
\mathrm{N}\end{array}$ & 13 \\
\hline & & Expected $\mathrm{N}$ & 99 \\
\hline \multirow{2}{*}{\multicolumn{2}{|c|}{ No area restrictions }} & $\begin{array}{c}\text { Observed } \\
\mathrm{N}\end{array}$ & \\
\hline & & Expected $\mathrm{N}$ & 99 \\
\hline \multirow{2}{*}{\multicolumn{2}{|c|}{ Timely feedback }} & $\begin{array}{c}\text { Observed } \\
\mathrm{N}\end{array}$ & \\
\hline & & Expected $\mathrm{N}$ & 99 \\
\hline \multirow{2}{*}{\multicolumn{2}{|c|}{ Rich learning methods }} & $\begin{array}{c}\text { Observed } \\
\mathrm{N}\end{array}$ & 8 \\
\hline & & Expected $\mathrm{N}$ & 99 \\
\hline \multirow{2}{*}{\multicolumn{2}{|c|}{$\begin{array}{l}\text { Rich teaching } \\
\text { methods }\end{array}$}} & $\begin{array}{c}\text { Observed } \\
\mathrm{N}\end{array}$ & 12 \\
\hline & & Expected $\mathrm{N}$ & 99 \\
\hline \multirow{2}{*}{\multicolumn{2}{|c|}{$\begin{array}{l}\text { Cultivate students' } \\
\text { thinking innovation }\end{array}$}} & $\begin{array}{c}\text { Observed } \\
\mathrm{N}\end{array}$ & \\
\hline & & Expected $\mathrm{N}$ & 99 \\
\hline \multicolumn{4}{|c|}{$\begin{array}{l}\text { Finally, the questionnaire surveyed which te } \\
\text { students prefer. Among them, } 10.09 \% \text { of the } \\
\text { online teaching, } 34.7 \% \text { of people like offl } \\
\text { teaching, and } 55.21 \% \text { of them like blended te }\end{array}$} \\
\hline \multicolumn{4}{|c|}{ Table 5 Result Analysis } \\
\hline \multicolumn{4}{|c|}{ Students prefer the teaching method } \\
\hline \multirow{4}{*}{ Valid } & Way & Frequency & Percent \\
\hline & On-line & 32 & $10.09 \%$ \\
\hline & Off-line & 110 & $34.7 \%$ \\
\hline & $\begin{array}{l}\text { Mixed } \\
\text { type }\end{array}$ & 175 & $55.21 \%$ \\
\hline
\end{tabular}

\section{DISCUSSION}

\subsection{National Policy}

From the perspective of national policies, our country is committed to developing blended teaching. On March 4, 2020, the General Office of the Ministry of Education of our country issued The Key Points of Educational Informatization and Network Security in 2020. This document clarified the train of idea of education informatization, advocated the need of vigorously develop "Internet + education", strengthened the education management information transition and upgraded of the education informatization in our country. In addition,

\subsection{Student Ability}

From the perspective of students' ability, self-discipline ability is varied from person to person. In fact, when it mentions that if network teaching can meet the learning needs of daily life, students will first consider whether their own self-discipline can meet their requirements for accepting knowledge or even how much they can learn in this environment. Moreover, the low-grade students have too narrow knowledge of network equipment, and the specific operation of the equipment may go beyond their domain of knowledge. 


\section{CONCLUSION}

Through the investigation, it is found that the primary reason that students believe that network teaching can meet their daily learning needs is that there is no regional restriction, resource sharing is the second reason that they can meet the learning needs, and the last reason is that network teaching can enrich the educational methods in our country. The first reason why students do not think that network teaching can meet their daily learning needs is that students' poor self-discipline ability, and the second reason is the difficulty of management, which shows that students are more psychologically inclined to teachers' control rather than self-restraint. The third reason is the poor interaction between teachers and students and the lack of communication between students, which shows that faceto-face communication conveys information better than network communication. According to the above results, there are three factors for students to consider whether network teaching can meet their learning needs: national policy, environmental factors and personal ability.

\section{ACKNOWLEDGMENT}

We express our deep gratitude to all students who participated in this survey.

\section{REFERENCES}

[1] Root W B and Rehfeldt R A, "Towards a ModernDay Teaching Machine: The synthesis of Programmed instruction and online education," J. The Psychological Record, April 2020. DOI: 10.1007/s40732-020-00415-0

[2] L. Xiang, L. Zhang, and J. Peng, “A study on china's fundamentals of college computer online education platform," J. Agro Food Industry Hi-Tech, 2017, vol. 28, pp. 98-100.

[3] Al-Neklawy and A. Farid, Online embryology teaching using learning management systems appear to be a successful additional learning tool among Egyptian medical students. J. Annals of Anatomy-anatomischer
Anzeiger, 2017:S0940960217300882. DOI: https: //doi. org/10.1016/j.aanat.2017.07.001

[4] T. Smith, E. Maiden, and M. Abinader, "Using students' perceptions of online teaching and learning to inform faculty development," J. 2019, vol. 18, pp. 301330 .

[5] S. Liu, D. Guo, and J. Sun, "Map On Learn: The use of maps in online learning systems for education sustainability," J. Sustainability, December 2020. DOI: $10.3390 / \mathrm{su} 12177018$

[6] Wu Jinna and Zhu Xuhui, “A research on the teaching strategies of network and new media practice in the new media era - taking adobe illustrator as an example," J. Journal Of Sui Hua University, 2015, vol. 35, pp. 119-121. DOI: CNKI:SUN:SHSZ.0.2015-08036(In Chinese)

[7] Yu Leixin, Xu Shanshan, and Zhang Yunli, “An Analysis of the Blended teaching mode of online and offline under the new situation," J. Modern Rural Technology, 2020, p. 98. DOI: 10.26914/c.cnkihy. 2020.012278 (In Chinese)

[8] Pei Jinhong, Wu Cuiling, and Li Xueqing, Cao Yanqing, "Practice and reflection on the comprehensive quality-oriented "completely on-line teaching mode," Chemistry of life: pp. 1-3, October 2020. DOI: http: //doi. org/10.13488/j.smhx.20200137 (In Chinese)

[9] Lu Zhaoyang, Zhang Zhiping, and Jing Yanyan, "The development of university network teaching during the new crown pneumonia epidemic," J. Education and Teaching Forum, 2020, pp. 143-145. DOI: CNKI: SUN: JYJU.0.2020-43-060 (In Chinese)

[10] Qian Xinxin, "Research and discussion on online teaching mode," J. Technology Wind, 2020, pp. 29-30. DOI: 10.19392/j.cnki.1671-7341.202027016 (In Chinese) 